\title{
THE GOVERNMENT OF A METROPOLITAN REGION
}

\section{Winston W. Crouch $\dagger$}

Metropolitan areas in all parts of the United States suffer from an excess of governmental units and from a lack of machinery that is sufficiently flexible to keep up with the ever extending urban sprawl. Students of metropolitan problems generally agree that there is a critical need to deal with the metropolis as a whole. To do this in most instances will call for imaginative inventiveness. Although in a sense a metropolitan area is a "local" area, in contrast to the state or the nation, in another sense it is a different thing than the county, the city or the township, the traditional units of local government. Are we to destroy these traditional units in the metropolitan areas? Should we further complicate the structure of government by creating yet another level-the metropolitan municipality? Probably each metropolitan area will evolve something that is peculiar to its area, born out of the peculiar needs, political history and economy of the area. Let us examine the efforts made in one area to do that.

\section{Definition of the Metropolitan Area}

Before one can speak effectively of the problems of governing the Los Angeles metropolitan region, one must establish a working definition of the region being discussed. Such a definition is a basic necessity not only because the requirements of logical discussion compel it but also because the metropolitan region does not exist in law as a unit of government. The task of marking out a definition is made more difficult, however, by the fact that there is no widespread agreement as to what criteria shall be applied in identifying metropolitan regions generally as phenomena of urban development, nor is there agreement as to how the Los Angeles region in particular should be demarcated.

If we are to take the definition of a standard metropolitan area proposed by the United States Bureau of the Census and accept its application to the Los Angeles area, we have a definition that follows a generally useful norm and one which is widely understood. The Los

$\dagger$ Director, Bureau of Governmental Research, and Chairman, Department of Political Science, University of California (Los Angeles). A.B., 1929, Pomona College; M.A., 1930, Claremont College; Ph.D., 1933, University of California (Berkeley). 
Angeles metropolitan area, according to census standards, is that urban agglomeration within the borders of Los Angeles and Orange counties. ${ }^{1}$ Within that area are two counties, fifty-eight municipalities, sixty-seven special districts and 171 school districts, or a grand total of 298 governing units. ${ }^{2}$ No one unit of local government has full responsibility for serving the needs of this metropolis except for water supply. The Southern California Metropolitan Water District serves this area and several others adjacent to it.

Linkage of Los Angeles with Orange county is becoming more pronounced year by year. Urban development has spread from Los Angeles southeastward across the county line to meet a similar outsurging from the Santa Ana-Anaheim communities of Orange County. The agricultural areas that once separated the two are rapidly giving way to subdivisions and industrial developments. Along the coastal area a continuous line of urban communities stretches from Malibu and Pacific Palisades in Los Angeles County through Orange County to San Clemente, located on the northern edge of San Diego County.

The census definition of a metropolitan area, as applied particularly to Los Angeles and its environs, is not fully satisfactory, however. It does not permit us to go really to the root of the assignment given this paper: analysis of the government of a metropolitan area as a political unit. The pattern of urbanization in the area surrounding the City of Los Angeles has been a fanning out in so many directions that no longer may one say with full satisfaction that the metropolitan area is confined either to one county or the combination of two counties selected by the census. The Census Bureau recognizes San Bernardino-Riverside as a separate metropolitan area, yet this area is closely related to Los Angeles and Orange counties and the four are joined by many ties. Urban development tends to fill in the former open spaces and to present one pattern of urbanization which extends from the ocean to the mountain ranges that backstop the San Bernardino and Riverside communities. This urban area involves only a portion of the total land areas of San Bernardino and Riverside counties. Both counties include within their governing jurisdictions vast tracts of mountainous and desert areas which, in spite of phenomenal development since 1947, are not urban and which must for a long time be considered as hinterlands to the metropolitan area.

1. U.S. BUREaU of THE CENSUS, Dep'T of Commerce, STATE and Local Govern-

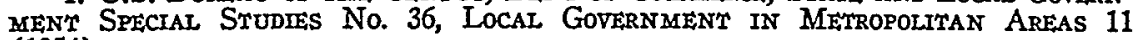
(1954).

2. See 1 U.S. Bureau of THE Census, Dep't OF COMMERCE, 1950 Census of Population \& 5-5. 
On the northwestern fringe of the metropolitan area tentacles of urban development now stretch from Los Angeles City into Ventura County, where additional urbanization is taking place. Although there is some interrelationship between Los Angeles and Ventura, it is doubtful if the Ventura area can properly be defined at present as being within the metropolitan area.

A more satisfactory definition of the metropolitan area of Los Angeles would include the urbanized area in the coastal plain of southern California that is surrounded by the Los Angeles ranges of mountains. ${ }^{3}$ This definition would trim away the northern part of Los Angeles County and approximately four-fifths of the land area of San Bernardino and Riverside counties which comprise desert and mountainous areas. Although these areas have close economic relationships with the urbanized area, and a considerable amount of development is now taking place within them, they do not constitute natural, geographic parts of the metropolitan region.

If we are to use contiguous (or approximately contiguous) urban development as the criterion for measuring the extent of a metropolitan area, we arrive at a very different picture than that produced by the Census Bureau definition. This new, redefined metropolitan area would include portions of four counties and would include sixty-nine incorporated cities.

Although contiguous urban development alone does not give a completely satisfactory criterion, it does coincide with some other features that are pertinent to the definition of this particular area. This urbanized region stretches out upon a coastal plain onto which the drainage from the surrounding mountains flows. Even though the creeks and rivers do not join into one central drainage system, there is an element of common interest in flood protection and in conservation of ground water resources. Furthermore, because the local water resources of the region are insufficient to serve the urban needs, the sub-parts are bound together by a common interest to ensure that adequate resources be imported from other watersheds.

The area has a number of other interests in common as a result of recent urban developments. One of these is air pollution. The concept of an "air drainage area" is very new in metropolitan-problem thinking. When an air pollution control district was created for Los Angeles by the state legislature in 1947, political forces and current thought on the problem combined to provide machinery to deal with the air pollution problem only in the more densely populated and heavier

3. Glendinning, Major Land Form Divisions of Califormia, in CALIFoRNIA AND THE SouthWEST 1, 7-8 (Zierer ed. 1956). 
industrialized area represented by Los Angeles County. It was thought that air pollution was solely a matter of concern for the center of the metropolis. Since 1947 it has become more clearly evident that the area affected by the problem is much greater than that placed within the district by law. On a truly smoggy day the urbanized area in the four counties is overhung with a pall to which the industrial plants, chimneys, incinerators and automobiles of the entire area contribute. Industries in San Bernardino and Riverside contribute to the smog over Los Angeles. Likewise, for decades the city dwellers of Los Angeles have been uncomfortably aware that the citrus growers of San Bernardino and Riverside counties burned crude oil in their open orchard pots to protect their fruit from December frosts.

The highway and street pattern, together with the automotive travel bent both upon pleasure and business, tends to emphasize the interrelationships of the various parts of this metropolitan area. Lake Arrowhead in the San Bernardino mountains, Palm Springs and Mt. San Jacinto in Riverside County and Newport-Balboa in Orange are recreation centers that serve the entire metropolitan area and are to be reached from any point within it by a few hours' driving. Traffic studies. also have disclosed a network pattern of automotive commuting set by the region's residents in travel between industrial establishments and homes. Apparently workers in Los Angeles and its environs are not yet concerned about living near their place of employment. The state's program of freeway construction appears to be encouraging the tendency to spread the urban growth still further throughout the entire coastal plain.

Other evidence of factors that tend to tie the various parts of the greater metropolitan area together includes that of the circulation of metropolitan newspapers which carry news and advertising from suburban communities as well as from the older business center. Yet another is the trend whereby downtown Los Angeles department stores construct major "branch" stores in outlying portions of the metropolitan area, thus duplicating the facilities formerly found only at the center. It is true, of course, that in many of the larger suburban cities there are important newspapers and department stores that identify themselves more particularly with a portion of the area, and compete vigorously with their metropolitan rivals in specific suburban areas.

In sum, there are numerous factors that tend to give a semblance of social and economic unity to this vast urban complex. At the same time there are numerous sub-centers of activity and political leadership within the area. Each of these factors need to be kept in mind in any study of the governance of the metropolitan area. 


\section{The Present Governmental Pattern}

No one unit of local government presently serves the entire metropolitan area. Only the state is responsible for ensuring that adequate governmental services are provided the inhabitants, and most services of a "local" nature have been delegated by the state to counties, cities and special districts.

In the Los Angeles County portion of the metropolitan area the county government is an important integrating element. It plays this role through a variety of administrative patterns. In part it does so by providing services financed by general county funds. Second, it provides a number of services, both for cities and for suburban communities, which are paid for by special taxes. Third, the county provides a number of services to cities within its borders in accordance with contracts. Finally, the county board of supervisors also sits as the governing body of two major special districts and is represented on several others which have significance for the governance of the metropolitan area.

\section{General County Services}

Counties in California have authority to undertake many municipaltype services in addition to those activities normally identified with rural governments. Los Angeles County, for example, provides many services to residents of unincorporated areas that are similar to those provided city residents by municipalities. The sheriff conducts a municipal-type police service; the road department builds and maintains urban-type streets as well as rural roads. The county health department provides inspection, sanitation enforcement and clinic treatment for persons residing in unincorporated areas and for residents of all but two of the incorporated cities in the county. The county recreation department maintains regional parks, golf courses, neighborhood recreation areas (in unincorporated areas) and swimming beaches that are patronized by suburban and city dwellers alike. The county fire chief directs two fire suppression units: the mountain fire patrol (paid by general taxes) and county district forces (supported by district taxes). The county charities department administers outdoor relief throughout the county, and conducts four general hospitals and two tuberculosis sanatoria to serve the entire county.

\section{Special-Tax Services}

Functions administered under county management and financed by district taxes include library facilities, fire protection and street 
lighting. All unincorporated territory is included in the library district and twenty-two incorporated cities have chosen to place themselves within it. ${ }^{4}$ The county library department serves all areas within this district. Eight fire protection districts have been organized in unincorporated territory, and all personnel and equipment within them have been placed under the unified direction of the county fire chief. County street lighting districts are simply special assessment districts to pay costs of improvement and maintenance work done in the benefited areas by the county road department. All of the districts considered here are governed by the county board of supervisors and hence do not add to the complexity of the governing set-up of the metropolis.

Another type of special district may be discussed separately, although in each case the county board of supervisors likewise constitutes the governing board. The Los Angeles County Flood Control District and the Los Angeles County Air Pollution Control District are examples. Each was created by a special state statute which made the county board ex officio the district board. Each district has the taxing power and employs its own staff separate from the county's (although each has its personnel work performed by the county civil service commission). In each case the legislature chose the special district device to provide machinery and legal power to deal with this problem rather than assign responsibility to the county under county government law. Thus, certain local government law difficulties were avoided while attempting to permit one county area to meet its needs. In one sense this choice kept the local government pattern simpler than any which would have resulted from creation of completely separate entities. Both districts have been involved in close relationships with municipalities. For the most part the flood district has enjoyed smoother relationships with the cities than has the air pollution unit. The flood district is required by law to receive the consent of any city through which any flood channel or spreading ground work is to be constructed. The recently conducted major storm drain program of the district involves even closer relationships: each city was permitted to determine the design and the location of drains in its area, subject to the coordinating supervision of the district, whose task it was to ensure that the needs of that portion of the metropolitan area in Los Angeles County were served. The Air Pollution District has been the target of attack from some city officials for failure to eradicate smog and for specific features of its enforcement program. At the same time the cities are responsible for removing and disposing of trash

4. Crouch, Intergovernmental Relations 69 (Metropolitan Los Angeles: A Study in Integration vol. XV, 1954). 
in a manner that will not contribute smoke and pollutants to the atmosphere. Until the cities or some metropolitan agency can provide satisfactory trash collection and disposal service, there will be friction between the respective jurisdictions and controversy over the role that incinerators play in the main problem.

\section{Intergovernmental Contracts}

Intergovernmental contracts have provided one of the most constructive methods of dealing with the problem of metropolitan government in the Los Angeles area. State laws have permitted extensive local option in developing contractual relationships and local administrators have been aggressive in working out the necessary arrangements. Most contracts are between Los Angeles County and cities within its borders. All but two cities contract to have the county assess property for tax purposes and collect municipal property taxes. ${ }^{5}$ Forty-four of the cities have transferred health services to the county, and most of them also contract with the county to enforce city health ordinances. Five contract for the issuance of building permits, and fourteen contract for personnel work to be done by the county civil service commission.

The contract system has been extended dramatically by the new city of Lakewood to the extent that this city of 71,000 population contracts with the county to supply all its services. The small number of Lakewood municipal employees functions to keep the city records and to act in liaison capacity between the local government and its constituents and the county government. Three additional communities that have incorporated during 1955-1956 have developed similar contracts, although they have not done so as extensively as has Lakewood.

Contract work undertaken by the county of Los Angeles is performed by the regular county departments in the same manner as normal county administration. All costs involved in the work, including administrative overhead, are itemized and included in the charges. Although the contracts are not cheap, most contracting cities believe that these arrangements cost them less than would their own administration of the same services. In most instances too the county can provide a higher quality of service with its larger and more experienced staff than could a small city. The most extensive use of county contracts has been made by the newer and smaller cities; the three largest cities, Los Angeles, Pasadena and Long Beach, have contracted for very few

5. Recent legislation permits cities and counties to levy sales taxes and to contract with the state to collect them along with the state sales tax. CAL. REv. \& TAX. CODE ANN. $\S \S 7200-07$ (West 1956). 
services. Los Angeles, however, has had the county assess and collect property taxes for many years, and it has often considered transferring its health services to the county.

Intergovernmental contracts and joint service arrangements have also been worked out between cities, and between cities and districts, in this metropolitan area. The best examples of this are in the administration of sanitary sewer systems. The city of Los Angeles owns and operates a major sewer system which includes a treatment plant and ocean outfall line, and it contracts with seven adjacent cities to allow them to make use of this system. The contracting cities contributed to the financing of the present treatment facility and continue to pay shares of the operating costs. As a result of the contractual arrangements the sewer systems of the eight cities are practically integrated in one system which serves a large portion of the central area.

\section{Special Districts}

A second metropolitan sewer system is conducted by the Los Angeles County sanitation districts organization. This system comprises a group of districts organized under state law. Some districts comprise several cities; most are composed of unincorporated areas and cities. Governing boards of the districts are made up of representatives of the city governments included within each district plus the chairman of the county board of supervisors. Each district finances construction and maintenance of major sewers by a district tax. An integrated trunk sewer system, treatment plant and ocean outfall line is maintained by the districts jointly. Administration of the joint system is vested in one district by agreement with the others, and the costs of the joint system are prorated. Although the district system's structure appears complicated, in practice it is a smoothly operating entity that has maintained good public relations for years and has exhibited strong leadership to meet the needs of its constituent areas. In recent years the districts have been authorized to undertake garbage collection and trash removal and disposal. Some of the districts have done this, although a carefully designed plan for metropolitan-wide waste disposal presented by the district staff has not been placed in operation. The chief element of success in the district system has been the leadership given by the central engineering staff. This leadership has been successful in emphasizing the unity of the districts' interests. The district system serves most of the eastern section of Los Angeles County. The two sewer systems, Los Angeles City and the county district organization, together serve almost every portion of the metropolitan area within Los Angeles County. 


\section{Annexation and Incorporation}

A large portion of the metropolitan area has been organized into municipalities. By far the largest of these, both in terms of territory and of population, is the city of Los Angeles, the third city of the country. Most of the city's vast territory was brought under its jurisdiction by annexation between 1906 and 1930. Eight smaller cities, including Hollywood and the port community at San Pedro, gave up separate municipal existence to join it. However, by far the largest amount of lands annexed was either uninhabited or sparsely settled when it joined the city. The lure that induced almost every one of the annexed areas to join Los Angeles was the assurance of sharing in the city water supply that was acquired in 1910 and delivered to the municipality in 1915. Water has made possible the urban development that has taken place. Possession of a large water supply placed this one city in a pre-eminent position to determine much of the metropolitan development. The physical shape as well as the great size of the city of Los Angeles, which resulted from the enormous annexation developments, has also placed the city in a key position to effect most of the problems of metropolitan importance: sewage disposal, traffic control and transportation, land use planning, subdivision control, policing and fire protection.

In several of these matters the central city has exercised leadership among its neighbors. Its contract relations with other cities for maintaining a major sewer system has been noted above. It has also contracted to supply amounts of electric power from its generators at Hoover Dam to neighboring municipal systems. Its police department has worked in cooperation with neighboring departments and its police academy has trained recruits of other cities as well as its own. Its fire department has honored administrative agreements with other departments to provide stand-by service when other units are called to major fires. Fires on municipal borders are suppressed cooperatively with other departments. The net result of the fire administration arrangement is that personnel and equipment of the various departments operate in coordination to meet emergencies.

Political fear of the big city, however, led at various times to the incorporation of other communities to prevent the further expansion of Los Angeles. Some, such as Beverly Hills, San Fernando and Culver City, have been surrounded by the larger city. Along the eastern limits of Los Angeles a chain of smaller cities block it from further annexations. Integration of the metropolitan area by annexation to the core city stopped at approximately 1925. Since that date 
such cities as Long Beach, Pasadena and Glendale have expanded considerably but no one city is in a position to predominate in metropolitan considerations today. ${ }^{6}$

Until 1954 it appeared that an end of incorporating new cities had been reached in the Los Angeles area. In that year the large suburban area of Lakewood decided to incorporate rather than annex to Long Beach or to continue receiving county government service directly. Its plan of contracting for municipal services appears to have triggered interest among many other fast growing suburban areas to consider incorporating as cities. Additional incentives to incorporation have been the desire to obtain more extensive services than the county provides directly, plus the desire to control locally the land uses to be permitted within the area. Three successful incorporation moves (one in Los Angeles County, two in Orange) have been to protect dairy farms from urban encroachments! At least one other has been to prevent encroachment of industry into a residential area, whereas another has been proposed to protect industrial development. A veritable flood of twenty incorporation petitions has poured in upon the Los Angeles county board in 1955 and 1956. If all these proposals succeed, in the near future there will be few heavily populated fringe areas left unincorporated in Los Angeles County. The picture is not yet sufficiently clear to know if this is a help or a hinderance to achieving solution of metropolitan problems. It is helpful in that, by incorporating, the suburban areas assume more nearly the full cost of services rendered to them. It is by no means clear whether these communities will withdraw entirely from the county family or if they will find it satisfactory to contract for service and thus stay within a unifying framework. If each new city goes its independent way, the metropolitan area may be further "balkanized" and a solution be further delayed.

\section{Other Coordinating Factors}

An important instrument for bringing municipal officials in California together to consider mutual problems is the League of California Cities. The organization functions both state-wide and regionally. Monthly meetings of the Los Angeles County division of the League offer an opportunity for city officials of this area to consider matters of joint interest, although thus far there has been little attempt made to focus upon problems of a truly metropolis-wide character. The League also maintains a southern regional office in Los Angeles to serve southern California cities.

6. BIGGER \& KITCHEN, How THE CITIES GREW (Metropolitan Los Angeles: A Study in Integration vol. II, 1952). 
Because of the elaborate intergovernmental contracts and administrative arrangements briefly referred to above, the portion of the metropolitan area that lies within Los Angeles County has had for some years a local governmental framework in which to deal with many of its area problems. Furthermore, the peculiar fact that Los Angeles County has had the legal authority, the political leadership and the administrative will to provide municipal-type services has focused attention upon defining the metropolis as the area existing within Los Angeles County. As a result of these efforts some amount of metropolitan unity has been produced. However, as the urbanization sprawl spreads across county boundaries and joins other communities that have previously enjoyed separate identities, the problem becomes vastly more complicated.

County government in San Bernardino, Riverside and Orange is more nearly in the traditional mold. The first two have great rural areas to govern. Rapidly growing urban communities not previously incorporated have organized municipal governments to provide services, although much suburban fringe remains in county jurisdiction. Relatively few functions have been approached in the San BernardinoRiverside section by means of such concepts as the joint-government effort or the area-wide organization. Flood control work on the Santa Ana river has been undertaken for some years as a joint county matter, and the area has also come within the Southern California Metropolitan Water District in recent years. Other than these efforts, there has been no vehicle to cut across the boundaries of the traditional governments to meet the needs of the new urban growth.

Orange County is geographically more unified and is smaller than its two neighbors on the outer rim of the metropolitan area. Older cities, such as Santa Ana, Newport Beach and Anaheim, have grown tremendously in population and have annexed large adjacent tracts. Countering this development has been the move to incorporate new communities. Since 1953 six new cities have been organized in this county - a trend comparable in all respects to that taking place in Los Angeles County. Joint community action in Orange County has been developed in two functions: water and sanitation. The Southern California Metropolitan Water District provides the first, and Orange County sanitation districts system the latter.

County boundaries continue to stand as the great barriers to metropolitan integration except where the state has created some special unit, such as the water district organized independently of county governments. This particular district is composed of incorporated cities, municipal water districts and other public water authorities. 
Its functions are limited to the single task of supplying water to its constituent units.

It is questionable, then, whether the solution to those problems which have regional implication is possible solely in terms of the state creating special metropolitan districts to treat each problem as it forces itself upon public attention. The water district has functioned effectively, but the conclusion does not follow that one good thing can be satisfactorily duplicated five or six times and still produce the same public good. Multiplication of metropolitan districts will bring its own problems arising from lack of coordination.

\section{Metropolitan Area-Wide Matters}

What subjects appear at this date to have metropolitan-wide implications or involvements? Water supply has been recognized as one for approximately twenty years. However, water conservation has not been so regarded thus far. Insofar as conservation has been attempted, it has been conducted on a district basis. A number of interesting plans have been proposed and some limited water-spreading efforts have been engaged in to replenish the underground water tables. Responsibility for such work has been assigned to units that have less than region-wide jurisdiction. As the metropolitan needs for water increase in intensity the functions of the metropolitan water district might well be expanded to include a conservation and reclamation program.

Area-wide implications of air pollution have been commented upon previously. When the air pollution control district law was adopted, agricultural interests on the periphery of the metropolitan area resisted all efforts to bring them within a control organization. Urban interests were more concerned at the time with regulating certain industries. Therefore a district confined to one county area was created. Since that date, the other counties in this metropolitan area have been authorized to bring air pollution control districts into operation in their areas. In the meantime, however, the dispersion of industry and its related urban development has produced a situation that cannot be coped with adequately by units confined to county boundaries. The problem is truly region-wide.

Provision for the movement of traffic is also clearly a matter of regional interest. The economic and social interrelationships of the entire urbanized area are such as to cause vast numbers of the metropolitan inhabitants to move about regularly throughout large sections of the area. It is true at the same time, of course, that there are many sub-concentrations where a considerable percentage of 
the population performs most of its activities. But the dispersal of industries, of recreation centers and of residential areas, plus the yearround mildness of the climate, encourages extensive automobile travel throughout the region. This is a region that has grown to full stature since the automobile came into popular use. The road system of the region, rather than any public transit network, has determined the patterns of development for the region. In the early years of the present century the suburban electric system organized by the Pacific Electric Company had much to do with encouraging the flight to the suburbs. But the automobile soon supplanted the trolley car-the latter has practically disappeared. Today the only semblance of a metropolitan transit system is an exceedingly meager bus system, which is patronized by only a fraction of the population. The commuting hordes drive their automobiles and choke the freeways and streets to the point of overflow.

Freeways, which become the major arteries of transportation within the metropolitan area, are located and financed by the state. Undoubtedly the decisions made by the state highway commission in routing new freeways make significant impacts upon the communities within the region. Although public hearings are held and consultations are carried out with local authorities, in the last analysis the transportation pattern of the region is determined by a body of men appointed by the governor and operating on a state-wide basis. Likewise in the allocations of funds for construction, the state-wide interest in highway routes is likely to prevail.

Consideration of metropolitan needs for mass rapid transit facilities has been the project of a state-created transit authority during the past two years. Its recommendations have been based upon the concept that the greater metropolitan area should be the area for planning transit facilities, and also on the assumption that rapid transit should include both rail and road facilities. Due to the fact that this authority was created with limited terms of reference, it must await further legislative action if its proposals are to be implemented. Every public transit plan for a metropolitan area like that of Los Angeles must face a fundamental issue: Is the transit system to focus upon the relatively small central core of Los Angeles, or is it to link conveniently the numerous sub-centers of the region as well as the center? Sub-centers such as Pasadena, Long Beach, Santa Ana, Riverside, San Bernardino and Pomona are sufficiently established and conscious of their economic importance to demand a place in any transit pattern. They are in a sense solar systems in their own right, not satellites of a central sun. 


\section{The Shape of Things To Come}

Given the fact that several strong sub-centers of influence now exist in this metropolitan region, it would appear that some type of federation rather than a unitary structure would be the more practical for dealing with metropolitan-wide problems. At the same time it appears quite evident that the state, of necessity, must prepare itself for leadership. State legislation will be required to permit any federated forms of organization to come into being. Administrative agreements between existing agencies are practical only in determining how staffs shall be used cooperatively. They do not lend themselves to the financing and constructing of public works. Intergovernmental contracts work reasonably well within the jurisdiction of one county. Clearly defined extensions of authority would be necessary before one county could contract to serve another or the latter's local areas. Such contracts would always be vulnerable because their continuance rests so heavily upon the will of the body performing the work to continue serving others than its own constituency.

Some form of federated special districts may be necessary to finance and construct facilities or perform research and investigation, and to carry out a program for metropolitan mass transportation or for air pollution control. The example of the Southern California Metropolitan Water District is at hand, is familiar, and has survived the test of years of operation under changing economic and social conditions. It may provide a means to cope with a few of these problems which tend to show evidence of being area-wide in implication.

There is need at the same time to give attention to coordinated efforts to solve numerous other problems that extend beyond existing local government jurisdictions. Urban expansion is taking place so fast and pushing so far into the hinterlands of the metropolitan area that there may be greater need for devices of consultation and coordination. Local units of government are held to specific areas of jurisdiction. What is needed is something elastic or which can be expanded to encompass new sections of territory. This situation would seem to argue most strongly for greater state participation in metropolitan activities.

Metropolitan growth and spread in California is not confined to the Los Angeles or southern California area. There are at least five other metropolitan areas in the state recognized by the Census Bureau. Two, the San Francisco Bay area and the San Diego region, have problems similar to those in Los Angeles. Therefore, the matter cannot be shunned by the state as peculiar to one area. The old urban-versus- 
rural area conflict has been modified almost to the point of being obliterated. At the same time, the state cannot afford to leave the organized cities and the organized counties to battle it out for supremacy, nor to leave the various cities to struggle among themselves for preeminence in the metropolis. The facts of the situation are changing rapidly.

Local government is so strong in its protection of the home rule tradition that the state cannot expect to supplant the county, the city or even the special district in the metropolis. All must be considered and must participate. The state, by reason of its legal authority and its superior financial resources, is bound to play a leading role. It must do something more than play the passive role of adopting legislation after the local entities have compromised their differences. It must exercise a lead in reaching an acceptable solution. Probably the first step towards accomplishing this would be the appointment of a state study commission to analyze the impact of urban growth upon the state and its local government structure and to focus the attention of influential groups and individuals upon possible solutions of the governmental needs. ${ }^{\top}$

7. This was the recommendation of the California Assembly at a meeting held at Stanford University, Sept. 13-16, 1956, in cooperation with the American Assembly. See Calmornia STate Government: ITs Tasks and Organization (1956) (booklet of background papers prepared for the California Assembly and its participants). 